\title{
Two new Agyneta Hull, 1911 from the Asian part of Russia (Aranei: Linyphiidae)
}

\author{
Ава новых вида рода Agyneta Hull, 1911 из азиатской части \\ России (Aranei: Linyphiidae)
}

\author{
A.V. Tanasevitch \\ A.B. Танасевич \\ Institute of Ecology and Evolution, Russian Academy of Sciences, Leninsky Prospect, 33, Moscow 119071, Russia. \\ E-mail: tanasevitch@gmail.com \\ Институт проблем экологии и эволюции РАН, Ленинский проспект, 33, Москва 119071, Россия. \\ KEY WORDS: Spiders, Micronetinae, new species, Altais, Russian Far East. \\ КЛЮЧЕВЫЕ СЛОВА: Пауки, Micronetinae, новые виды, Алтай, Дальний Восток России.
}

ABSTRACT. Two new species of Agyneta Hull, 1911 are described: A. cuneata sp.n. from the Russian Far East, and A. metatarsialis sp.n. from the Altais, southern Siberia.

РЕЗЮМЕ. Приведены описания двух новых видов рода Agyneta Hull, 1911: A. cuneata sp.n. из Дальнего Востока России и A. metatarsialis sp.n. из Алтая.

\section{Introduction}

The spider fauna of Russia counts at least 40 species of the genus Agyneta Hull, 1911, 30 of which occur in Siberia and the Russian Far East. Another two new Agyneta species have been found in the collection of the Zoological Museum of the Moscow State University, Moscow, Russia (ZMMU); their descriptions are the subject of this paper.

\section{Material and methods}

All material is deposed in the ZMMU collection.

In the description, the sequence of leg segment measurements is as follows: femur + patella + tibia + metatarsus + tarsus. All measurements are given in $\mathrm{mm}$. Scale lines in the figures correspond to $0.1 \mathrm{~mm}$.

The terminology of genitalic structures follows that of Saaristo \& Tanasevitch [1996].

The following abbreviations are used in the text and figures: E - embolus; EP — embolus proper; Fe femur; L — lamella characteristica; Mt - metatarsus; $\mathrm{R}$ - radix; RA — radical apophysis; TA — terminal apophysis; Ti - tibia; TmI - position of metatarsal trichobothrium.

\section{Descriptions}

Agyneta cuneata sp.n.

Figs 1-9.

HOLOTYPE O' (ZMMU), RUSSIA, Amurskaya Area, Selemdzhinskiy District, island on Byssa River about $2 \mathrm{~km}$ upstream of Kukuya Rill mouth, 310 m a.s.1., mosses and leaf litter, 6.VI.2007, leg. E. Veselova \& A. Ryvkin.

ETYMOLOGY. The species name refers to the wedge-shaped palpal tibia.

DESCRIPTION. $\sigma^{7}$. Total length, 1.75. Carapace 0.85 long, 0.63 wide, greyish pale brown with a polygonal median spot. Chelicerae 0.38 long, not modified. Legs pale yellow-brown. Leg I, 2.81 long $(0.75+0.23+$ $0.70+0.63+0.50) ; \mathrm{IV}, 2.78$ long $(0.78+0.20+0.70+$ $0.65+0.45)$. Chaetotaxy. All tibiae with two dorsal spines, in addition Ti I \& II with a retrolateral spine; Mt I-IV spineless. Metatarsi I-III each with a trichobothrium. Tm I 0.27. Palp (Figs 1-9): Tibia with a wedge-like outgrowth directed at ca $45^{\circ}$ off segment's axis retrolaterad. Cymbium slightly conical, with neither processes nor tubercles posteriorly. Paracymbium simple, anterior and posterior pockets shallow. Radix with a stylet-shaped radical apophysis in distal part. Lamella characteristica short, gradually broadened distad. Terminal apophysis consisting of three parts: one long, stripe-like and two small ones. Embolus with a large tooth at its base. Abdomen 1.00 long, 0.63 wide, dark grey, almost black.

Female unknown.

TAXONOMIC REMARKS. The new species differs well from other congeners by the peculiar shape of the palpal tibia, as well as by the presence of the styletshaped apophysis in the distal part of the radix. Among the Siberian Agyneta, such an apophysis is only known in A. levii Tanasevitch, 1984.

DISTRIBUTION. Known from the type locality only. 


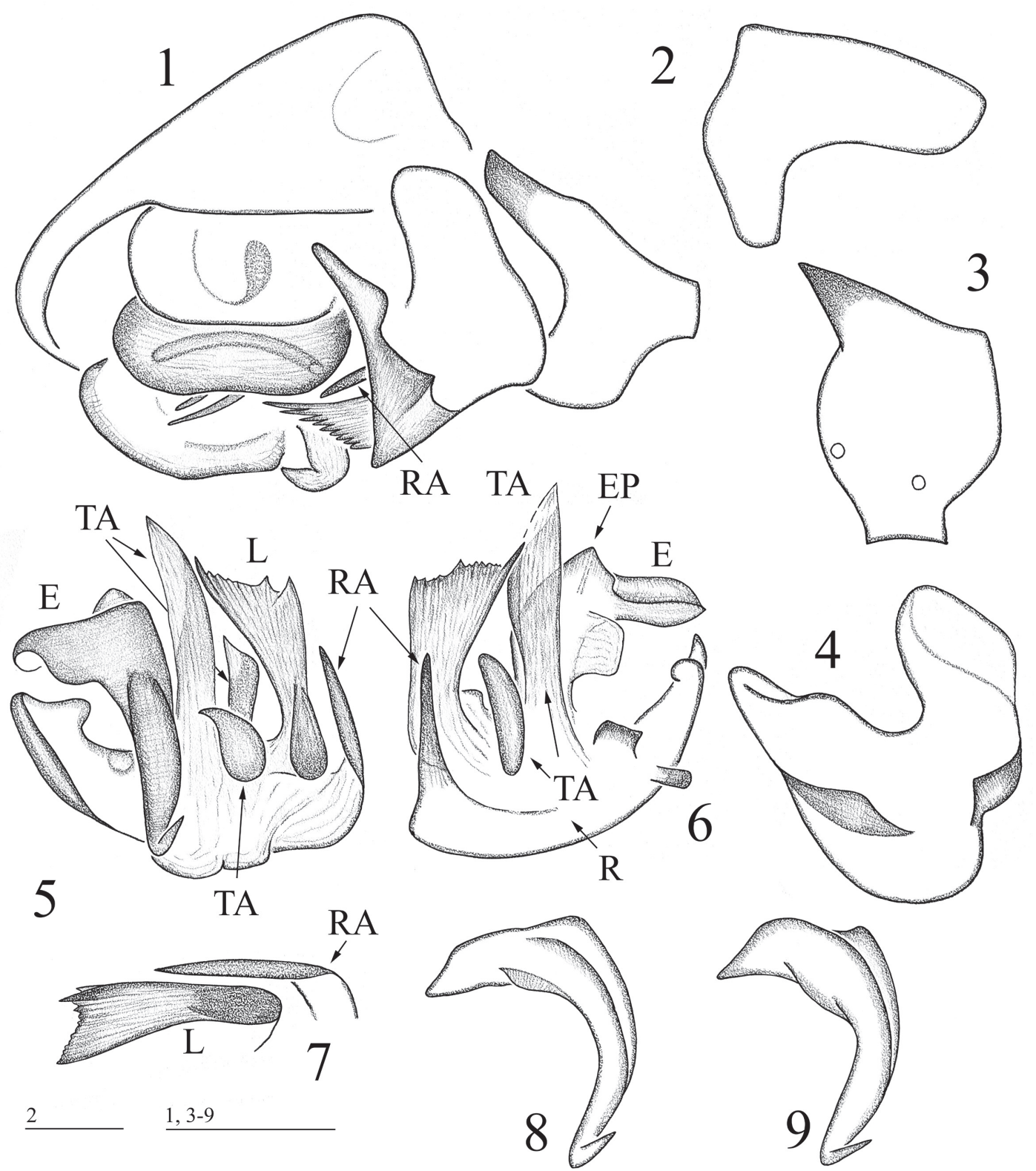

Figs 1-9. Agyneta cuneata sp.n., holotype: 1 - left palp; 2 - cymbium, prolateral view; 3 - palpal tibia, dorsal view; 4 paracymbium; $5 \& 6$ - embolic division, different aspects; 7 - lamella characteristica and radical apophysis; $8 \& 9$ - embolus, different aspects.

Рис. 1-9. Agyneta cuneata sp.n., голотип: 1 - левая пальпа; 2 - цимбиум, пролатерально; 3 - голень пальпы, дорсально; 4 парацимбиум; 5 и 6 - эмболюсный отдел, разные аспекты; 7 - lamella characteristica и радикальная апофиза; 8 и 9 - эмболюс, разные аспекты.

\section{Agyneta metatarsialis sp.n.}

Figs 10-17.

2004 Agyneta cf. unicornis. — Levina \& Mikhailov: 44. HOLOTYPE OT (ZMMU), RUSSIA, Republic of Altai, Choya Distr., Mt Baltyrgan, 2100 m a.s.1., alpine meadow, 4.VIII.2001, leg. N. Levina.

ETYMOLOGY. The species name refers to the specific shape of metatarsus I.

DESCRIPTION. $\sigma^{7}$. Total length, 1.73. Carapace 0.78 long, 0.60 wide, yellow-grey. Chelicerae 0.38 long, not modified. Legs pale yellow-brown. Leg I,
2.34 long $(0.63+0.20+0.58+0.50+0.43) ; \mathrm{IV}, 2.44$ long $(0.65+0.20+0.63+0.58+0.38)$. Metatarsus I weakly and gradually broadened as in Fig. 10. Chaetotaxy. All tibiae with two dorsal spines; Mt I-IV spineless. Metatarsi I-III each with a trichobothrium. Tm I 0.21. Palp (Figs 11-17): Tibia with a semi-lunar notch apically. Cymbium with a posteroventral outgrowth. Embolus strongly modified, with a flat, stripe-like process basally. Lamella characteristica S-shaped, relatively short and wide. Abdomen 1.00 long, 0.65 wide, dark grey. 


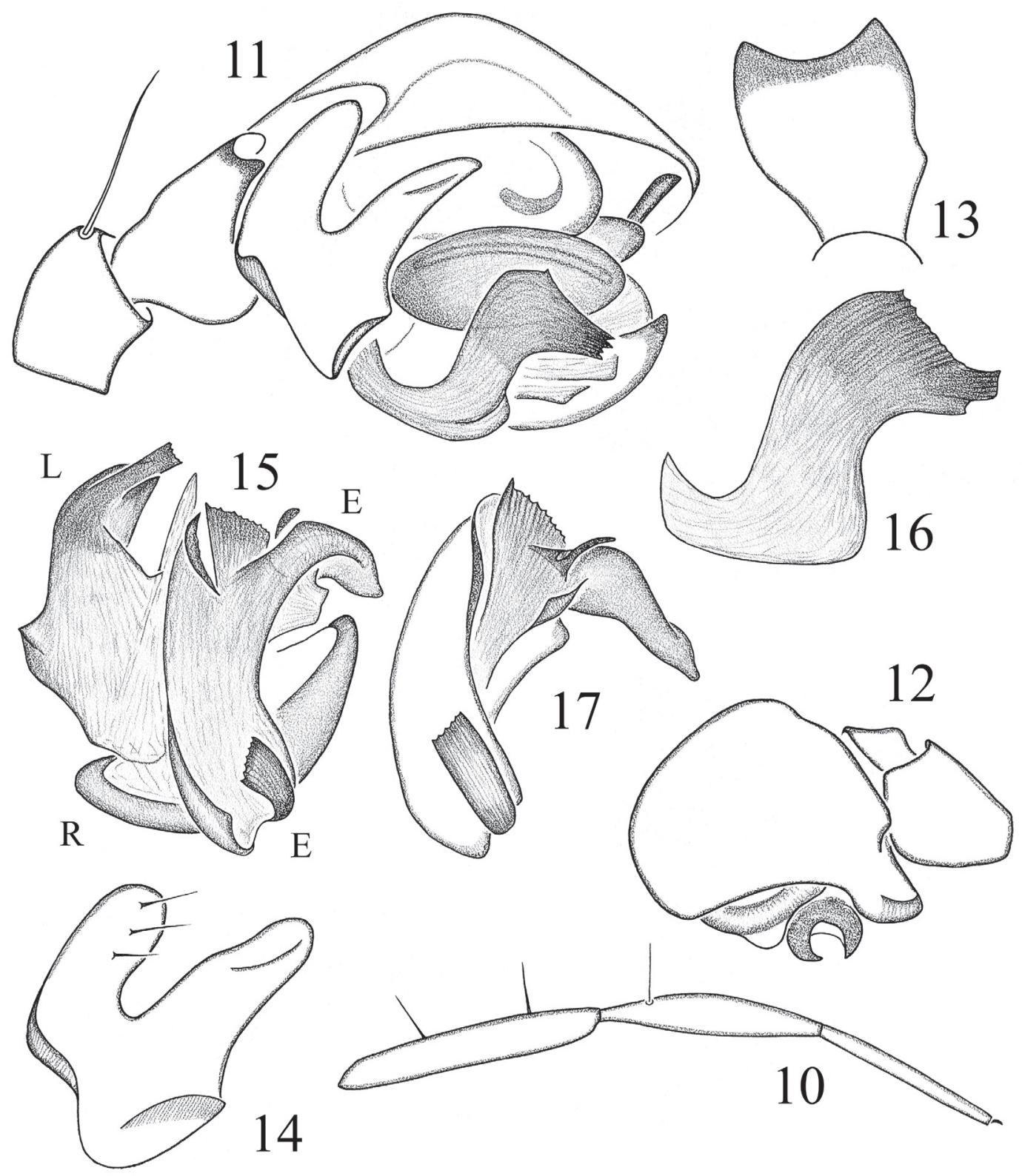

Figs 10-17. Agyneta metatarsialis sp.n., holotype: 10 - leg I; 11 - right palp; 12 - cymbium, prolateral view; 13 - palpal tibia, dorsal view; 14 - paracymbium; 15 - embolic division, 16 - lamella characteristica, 17 - embolus.

Рис. 10-17. Agyneta metatarsialis sp.n., голотип: 10 - нога I; 11 - правая пальпа; 12 - цимбиум, пролатерально; 13 - голень пальпы, дорсально; 14 - парацимбиум; 15 - эмболюсный отдел; 16 - lamella characteristica; 17 - эмболюс.

Female unknown.

TAXONOMIC REMARKS. The new species resembles A. unicornis (Tao, Li et Zhu, 1995), known from Changbai Shan Mts, Jilin Province, China [Tao et al., 1995], but is distinguished well by the smaller cymbial posteroventral outgrowth, by the shape of both lamella characteristica and embolus, as well as by the weakly broadened metatarsus of the first $\sigma^{7}$ leg. At least this latter character has not been mentioned in the original description of A. unicornis.

DISTRIBUTION. Known from the type locality only.

ACKNOWLEDGEMENTS. I am very grateful to all persons whose collections have been used here. I also thank S. Golovatch who kindly checked the English of an advanced draft. 


\section{References}

Levina N.V., Mikhailov K.G. 2004. [The spider (Aranei) fauna of the Mountainous Altais] // Byulleten' Moskovskogo obshchestva ispytatelei prirody. Otdel biologii. T.109. Vyp.3. P.38-52 [in Russian, English summary].

Saaristo M.I., Tanasevitch A.V. 1996. Redelimitation of the subfamily Micronetinae Hull, 1920 and the genus Lepthyphantes
Menge, 1866 with descriptions of some new genera (Aranei, Linyphiidae) // Ber. nat.-med. Verein Innsbruck. Bd.83. S.163-186.

Tao Y., Li S.Q., Zhu C.D. 1995. Linyphiid spiders of Changbai Mountains, China (Araneae: Linyphiidae: Linyphiinae) // Beitr. Araneol. (for 1994). Bd.4. S.241-288.

Responsible editors S.I. Golovatch, K.G. Mikhailov 